\title{
The Problem of Folklorism in Russian and National Literatures of the Early $20^{\text {th }}$ Century
}

\author{
Anna I. Oshchepkova \\ and Antonina A. Vinokurova* \\ M.K. Ammosov North-Eastern Federal University \\ 58 Belinsky Str., Yakutsk, 677000, Russia
}

Received 12.01.2018, received in revised form 30.03.2018, accepted 03.04.2018

The article clarifies and details the notion about the types of folklorism in Russian and national literatures of the $20^{\text {th }}$ century, which includes different forms of orientation to the oral tradition, as it is studied on the basis of the symbolist text and northern prose. Complex architectonics of the author's word, where stylization with the orientation to a "foreign" word becomes the determinate, is created in the symbolist text. The most vivid forms of folklorism transformation is stylization and imitation of folk poetry, which were most vividly expressed in the collected poems by Andrey Bely "Ashes". Another type of correlation between the literary text and folklore is determined not by the author's conscientious intent, but by the text or the language itself (such notions as "genre memory", "language memory", and "archetype" clearly demonstrate what is being said). This principle of folklorism is represented in the verses of the Even poet V. Lebedev. Lebedev's lyrics embodied the features of the ambiguous nature of the early literary tradition, which retains its genetic connection with the poetic tradition of the Even folklore.

Keywords: folklorism, folklore, symbolist poetics, stylization, imitation, genre, early literary tradition, Even poetry.

DOI: 10.17516/1997-1370-0252.

Research area: literary studies.

The problem of folklorism in the fictional texts of different literatures has a fundamentally different character. Herewith, the initial was the idea that the principal difference of any literature, regardless of its national and linguistic roots, is determined by the correlation between oral and written forms of literature, the typological differentiation of which was firstly undertaken in the works of M. Perry and A. Lord's school. In this regard, it appears to be interesting to consider different types of folklorism on the basis of Russian and Even literature of the early $20^{\text {th }}$ century.

The material of Russian poetry of the early $20^{\text {th }}$ century suggests the study of the issue of folklorism in literary text in the synchronic aspect, which is of more typological and theorized nature, it is characterized by the conscious and purposeful appeal to folklore. The synchronic approach is characterized by the specific literary folklorism, with its orientation to folklorism and folkloristics tradition, but not to folklore itself. The early works

(c) Siberian Federal University. All rights reserved

* Corresponding author E-mail address: oshchepkova.anna@mail.ru; antonina-vinokurova@bk.ru 
of Andrey Bely were taken as a material for studying this type of folklorism. A distinctive feature of the symbolist texts is mythology and folklorism (Z.G. Mints, E.V. Pomerantseva， G.A. Levinton, A.V. Lavrov). The issue of folklorism in the poetics of symbolism is naturally correlated with the theoretical and folkloristic works of Andrey Bely.

Another type of correlation between the literary text and folklore is determined not by the author's conscientious intent, but by the text or the language itself (such notions as "genre memory", "language memory", and "archetype" clearly demonstrate what is being said). This principle of folklorism is represented in the verses of the Even poet V. Lebedev. It is known that the essence of the recently put into writing literatures, which include the literature of the peoples of the North as well, is their indisputable reliance on folklore, although their connection with the literary tradition is acknowledged (E.M. Meletinsky, S.Yu. Neklyudov, G.A. Levinton, G.V. Gachev). A number of researchers of the literature of the peoples of the north found out that the genesis of the northern literature was determined by two factors: national folklore and Russian classics (M. Voskoboinikov, A. Burykin, V. Okorokova).

Folklore traditions in the collected poems by Andrey Bely "Ashes" (1908). As an epigraph to his collected poems "Ashes" Bely used the lines of the poem by N. Nekrasov ("Что ни год уменьшаются силы" [With every year the forces decrease]), dedicating his entire collection to his memory. Researchers have repeatedly noted that the direct inclusion of Bely in Nekrasov tradition influenced, above all, the genre level. Such rare for the early literary work of Bely characteristics, as storyline and a tendency to epic narration appeared in the collected poems "Ashes". It was already an obvious desire to overcome lyricism and a tendency to epization, to the epic origin. The poet develops the storyline in the poems "The Merchant", "The Date", "The Telegraphist", "The Gallows", and others: "Like Nekrasov", the researchers note, "Bely aims to the storyline development of the theme" (Skatov, 1988: 154). In this regard, it seems necessary to consider in which way the adoption of Nekrasov tradition influences the poetics of this collected poems.

For Bely, the first introduction to Nekrasov's literary work apparently started from June 1904, this exact time the poem "Troika" is dated. As indicated by a number of points this verse by Bely was written under the influence of "Troika" by Nekrasov. Accurate reproduction of the name of the famous poem by Nekrasov indicates of the reference to "someone else's text". In this case Bely uses quotation to "refer to the source". The text by Bely is characterized by paraphrases of Nekrasov's "source text".

\section{Nekrasov:}

И зачем ты бежишь торопливо

За промчавшейся тройкой вослед?

Не нагнать тебе бешеной тройки: Кони крепки и сыты и бойки, -

Все лицо твое вспыхнуло вдруг

Сквозь румянец щеки твоей смуглой

(Nekrasov, 1981: 62-63)
Bely:

Ей, помчались! Кони бойко

Бьют копытом в звонкий лед;

Разукрашенная тройка

Закружит и унесет.

\section{Чей румянец ярче вспыхнет}

На обветренном лице?

(Bely, 1966: 218-219) 
Paraphrasing is almost exact citation, with the selection of the key words from the source's text (“тройка" [troika], “кони бойки” [horses are bold] / "кони бойко” [horses boldly], “лицо румянец" [face - blush]). Bely obviously proceeds from Nekrasov's verbal motives. The motive of “промчавшаяся тройка" [the "troika rushing past"] described in Nekrasov's lines causes response in Bely verse: "Разукрашенная тройка" [Well-decorated troika] / Закружит и унесет [Will whirl and carry away]. It should be noted that Bely preserves Nekrasov's sound system of lines: alliterative consonance of hissing [ш] ([sh]), [ж] (zh) and sonorous sounds [p] ([r]) and [н] ([n]) (“И зачем ты бежишь торопливо [And why do you run in a hurry] / За промчавшейся тройкой восслед" [Behind the troika rushing past] (Nekrasov); “Разукрашенная тройка [Well-decorated troika] / Закружит и унесет [Will whirl and carry away]" (Bely)). Along with that Bely's text is characterized by a stronger sound instrumentation and sound sequence.

Among the references to the Nekrasov's poem there is also the syntactic structure of the rhetorical question, which is traditionally used in folklore text and is characteristic of Nekrasov: “Что ты жадно глядишь на дорогу [Why do you avidly look at the road] / В стороне от веселых подруг?" [Away from your merry girlfriends] (Nekrasov) - "Чей румянец ярче вспыхнет [Whose blush flashes brighter] / Ha обветренном лице?" [On the weather-beaten face?] (Bely). In the text by Bely, the description of the female character refers to the original source - the Nekrasov's character: "Все лицо твое вспыхнуло вдруг" [All your face flashed up suddenly], “Сквозь румянец щеки твоей смуглой [Through the blush of your swarthy cheeks].... / Смотрит бойко лукавый глазок" [Your playful eye stares boldly]. Here Nekrasov reproduces the type of folkloric description of girls' beauty - "blushy", "bold" and "merry".
Bely almost word-for-word conveys the main predicates in the female character characteristics: “... румянец ярче вспыхнет [blush flashes brighter] / На обветренном лице" [On the weather-beaten face], “...Улыбнется” [Will smile], that, in its turn, goes back to Nekrasov. Bely's orientation to folklore stylistics, mediated through Nekrasov, finds its expression in permanent epithets (“сырая могила" [damp grave], “корнет молодой” [young cornet], “алая лента" [scarlet ribbon] in Nekrasov's verse, and “молодой ямщик" [young coachman] in Bely's verse); in the folkloric expressions (in Nekrasov's verse: “Знать, забило сердечко тревогу" [It seems the alarm sounded in the heart], "И схоронят в сырую могилу” [And will be buried in a damp grave] /; in Bely's verse: "Ей, помчались!” [Неy, let’s rush!], “Здравствуй, молодец...” [Hello, fine fellow...]). Finally, the common thing for Bely and Nekrasov is that both poets use meters that traditionally go back to the folklore tradition. This is anapaestic trimeter or tetrameter in Nekrasov's verse and trochaic tetrameter in Bely's verse. At that, both meters reproduce the rhythm of the spoken language intonation.

Thus, the quotes in Bely's poem are a sign of a general orientation toward the citation of Nekrasov's text. The reference to the unique structure of "Troika", which is of explicit folklore nature, reveals Bely's orientation to Nekrasov's folklorism. Thus, Nekrasov's tradition influenced, first of all, the expansion of the lyric sphere by Bely, due to the narrative nature of the folk song. Melodiousness of Nekrasov's tradition was reflected in the poetics of "Ashes" at the plot, stylistic and rhythmic levels.

Folklorism in the poetry by V.D. Lebedev. Vasily Lebedev is a distinguished Even poet of the $20^{\text {th }}$ century. V.A. Robbek, one of the authoritative researchers of the northern literature, believed that the works of Even poets "come from the oral 
folk art" (Keptuke, Robbek, 2002: 5). The early poetry of V. Lebedev reflects inexhaustible plots and motives of the Even people's folklore. Literary works by Lebedev are one of the first literary texts in northern literature, which managed to convey the unique genre nature and stylistic richness of the Even folklore and language.

The most popular song in the Evenki verbal folk art is called "alma" ("song - imitation"), and this is the reason why V. Lebedev often uses this

Урэкчэр хэетэн мэңэнь авларакатан

Хэелэн хо гудей асаткан тэгэттэн

Тэгэли хигили икэнни делчилран!

(Lebedev, 1968: 20) genre in his poetry. For example, in the poem "Ike" we can see the features of the "alma" genre poetics. Thus, in the structure of this literary work, we can identify three compositional parts of lyrical development inherent to the folklore song:

1) Introductory part of the theme: the poet glorifies the song of a beautiful girl sitting on a hill, against the background of a multicolored rainbow.

When the top of the mountains is illuminated by the sun

A beautiful girl is sitting,

And her song can be heard for a long distance! (translated by A. Vinokurova)
2) Development of the theme: the song of the girl is intertwined with the song of a bird in the

Мучитэч унңэттти исагла делбэрэч

Чивкачан икэнни эрэли дэлчилрэн, Амкачан хэелэн тэгэтти асаткан Икэрин гөмкэнни өмэтту хамулран, summer forest, and their songs sound in unison to this warm sunny day.
A bird's song can be heard,

The sounds of the songs of the girl sitting on the hill, Sound in unison to this warm sunny day.
3) The climax of the theme: this wonderful song is heard by a young man-reindeer herder, and he is pleased to return from the pasture at night, hearing the singing of the beautiful girl and the bird.
Эмэдди омалга кориттан алтаттан

Явчинач омалга дюлаи эмривэн

Тачимур одакалан

Гургэ инэңтэн бакалдар муттулэ.
On his way back a young man hears the singing of the girl

Going home from the night pasture

In such a way she will

Always meet him from his night work.
Thus, it is revealed that the structure of this verse corresponds to the structure of the folklore genre of alma-song of Evens. In addition to structural similarity, there is also a thematic proximity. Alma-songs are characterized by the motives of memories about the past, sad or merry past, the description of nature, mountains and rivers associated with some significant events. 
In this verse, the characters also experience an emotional uplift when they recall the past happy days in their memory.

In the verses by V. Lebedev, the orientation towards the epic narration traditions is clearly visible. "Archetypal motives of travels" form the basis of the verses' plots (Lotman, 1998: 65). These travels, as a rule, are strictly correlated with mythological loci, with the opposition of the sky, the area of the underground and underwater "world" (Lotman, 1998: 65). For example, in the verse "Mirgilan", during the spell the soul of the shaman (дэ5сэн бисни няниндули) flies into the sky, floats away into the sea turning into a fish, and flies over the rocks and meadows. Imitating the story-teller of the epic narration, Lebedev denotes the river as the boundary between the real and the surreal worlds.

The next folklore genre, identified in the literary works by V. Lebedev, is orkachin. From the conversation with the oral tradition carriers (E.N. Bokovaya, E.I. Khabarovskaya and M.S. Tolstova) we found out that in the lexis of the Even folklore text there is a colloquial genre orkachin, which in translation into Russian means biting words, humour. In the poetic literary work by V. Lebedev there are three satirical poems: “Дярган икэ” (Song-Calling Names), Бэругэн (Lost) and Бэгэн гян (Friend of the Boss). In “Дярган икэ” (Song-Calling Names) the lyrical character derides the behavior of the girl who talked scandal about the young man and, as a result, became lonely.
Thus, Vasily Lebedev is a poet who creatively processed the song and epic genres of northern folklore, thereby preserving the unique cultural heritage of Evens.

Thus, in Russian poetry of the early $20^{\text {th }}$ century, as demonstrated by the study of Nekrasov's traditions in the collected poems by Andrei Bely "Ashes", there are different variations in the para-folkloristic nature of the text (G.A. Levinton, V.N. Toporov), composition of the plot and stylistic features of which, with all the apparent folkloristic nature, are already a phenomenon of a literary practice. These texts apparently evidence of not only the typological convergence and divergence of the two types of texts (folklore and literary), but also of the peculiar borderline of the symbolist texts with their sharpened focus on the language, of the stylistic pun of the genre-stylistic layers of folklore, starting from the "speech genres" (M.M. Bakhtin' understanding), the language environment of proverbs and sayings, and finishing by formula expressions. While V. Lebedev's lyrics embodied the features of the dual nature of the early literary tradition, which retains its genetic connection with the poetic tradition of the Even folklore. This kind of consideration gives an opportunity to give detailed distinction between the types of interrelation of literary texts and the oral tradition, to determine the specificity of the folkloristic nature of literatures belonging to different national and linguistic roots.

\section{References}

Bely, A. (1966). Stikhotvoreniia i poemy [Verses and Poems]. Moscow-Leningrad, Sovetskii pisatel', $656 \mathrm{p}$.

Nekrasov, N.A. (1981). Sobranie sochinenii i pisem: v 15-ti t. [Complete Works and Letters: in 15 Vols]. Leningrad: Nauka, 1, 540 p.

Keptuke, G., Robbek, V. (2002). Tungusskii arkhaicheskii epos: evenkiiskii i evenskii geroicheskie skazaniia [Tunguska Archaic Epos: Evenki and Even Heroic Legends]; Russian Academy of Sciences, 
Siberian Branch, Institute for Humanities Research and Indigenous Studies of the North. Yakutsk, Publishing House of ISNPN SB of the RAS, 210 p.

Lebedev, V. (1968). Дялбу төрэңнэтэн. Yakutsk, Нека төрэңэн книга издательстван, 64 p.

Lotman, Yu.M. (1998). Poeziia i proza [Poetry and Prose], In Stikhovedenie: Khrestomatiia [Study of Poetry: Reader], Compl. By L.E. Lyapina, $2^{\text {nd }}$ edition, revised and enlarged. Moscow, Flinta: Nauka, $248 \mathrm{p}$.

Skatov, N.N. (1988). "Nekrasovskaia kniga” Andreia Belogo ["Nekrasov’s Book” by Andrey Bely], In Andrei Belyi: Problemy tvorchestva [Andrey Bely: Problems of Creative Work]. Moscow, Sovetskii pisatel', $832 \mathrm{p}$.

\title{
Проблема фольклоризма в русской и национальных литературах начала XX века
}

\author{
А.И. Ощепкова, А.А. Винокурова \\ Северо-Восточныий федеральный университет \\ им. М.К. Аммосова \\ Россия, 677000, Якутск, ул. Белинского, 58
}

\begin{abstract}
В статье уточняется и детализируется представление о типах фольклоризма в русской и национальной литературах XX века, включающей в себя разные формы ориентации на устную традииию, так как рассматривается на материале символистского текста и северной про3ы. В символистском тексте создается сложная архитектоника авторского слова, определяюшей в котором становится стилизация с установкой на «чужое» слово. Наиболее яркими формами трансформащии фольклоризма становится стилизация и имитация народной поэзии, получивших наиболее яркое выражение в сборнике стихотворений Андрея Белого «Пепел». Другой тип соотношений литературного текста с фольклором определяется не сознательным намерением автора, а самим текстом, языком (такие определения, как «память жанра», «память языка», «архетип» достаточно ясно показывают, о чем идет речь). Такой приниип фольклоризма представлен в поэзии эвенского поэта В. Лебедева. Лирика В. Лебедева воплотила в себе черты двойственной природы самой раннелитературной традиции, сохраняющей свою генетическую связь с поэтической традищией эвенского фольклора.
\end{abstract}

Ключевые слова: фольклоризм, фольклор, символистская поэтика, стилизация, имитация, жанр, раннелитературная традиция, эвенская поэзия.

Научная спеииальность: 10.01.00 - литературоведение. 